\title{
Trends and Issues of 'Other Income' Tax Administration in Ethiopia: A Case for ERCA West Addis Ababa Branch
}

\author{
Tesfamlak Mulatu Mune \\ Department of Accounting and Finance, College of Business and Economics, Injibara University \\ PO box 40, Injibara, Ethiopia
}

The research is self-Sponsored

\section{Abstract}

The main objective of this study was to examine schedule ' $\mathrm{D}$ ' income known as 'other income' tax administration trends and issues in Ethiopia at ERCA West Addis Ababa Medium Taxpayers Branch. To achieve this objective both primary and secondary data were employed and descriptive research design was used. The major findings of the study indicated that the branch office plans and collections of taxes levied on other income was limited to income from dividends, winnings of game, capital gain on share of stock, royalties, and interest on deposit among others. Besides most of these taxes collection by the branch office went down and declining throughout the recent three years. Less efforts made by the branch office in providing information technology, law enforcement, imposing penalties, developing organized data handling system, and awareness creation accompanied with noncompliance and tax evasion of the taxpayers were the main causes for other income tax administration inefficiency. The study also revealed that low compliance level of other income taxpayers couldn't arises from the taxpayers' knowledge gap rather it could be raised from the low tax moral and attitude of taxpayers towards paying tax.

Keywords: Ethiopia, other/schedule ' $\mathrm{D}$ ' income, tax administration

DOI: $10.7176 / \mathrm{DCS} / 9-7-02$

Publication date:July $31^{\text {st }} 2019$

\section{Introduction}

The revenue of the Ethiopian government comes from different sources such as tax, public borrowing, sales of public assets, and transfer payments. The main purpose of generating revenue from these various sources is to finance government expenditure. These public expenditures are meant for public goods and services that are very essential for the development and wellbeing of the society (Gebremariam, 2010). Among the various aforementioned sources of revenue, taxes are the primary and sustainable source of government revenue (Ayele, Getnet, \& Bekalu, 2017).

A tax (from the Latin taxare: to estimate, which in turn is from tangere: to touch) is be defined as a "a compulsory contribution payable by an economic unit to a government without expectation of direct and equivalent return from the government for the contribution made" (Graetz \& Schenk, 2001). Tax administration refers to the identification of tax liability based on the existing tax law, the assessment of this liability, and the collection, prosecution and penalties imposed on recalcitrant taxpayers. Tax administration, therefore, covers a wide area of study, encompassing aspects such as registration of taxpayers, assessments, returns processing, collection, and audits (Kangave, 2005). Tax administration therefore, should aim at improving on laws regarding the registration, assessment, collection revenue, and exploiting fully taxation potential of a country (Asian Development Bank, 2001).

In Ethiopia, Ethiopian Revenue and Customs Authority (ERCA) is the authority dealing with taxes at federal level and there are different tax administrators at each branch, which ERCA West Addis Ababa Medium Taxpayers' Branch is the one. The taxes levied and collected by the authority consist of direct and indirect taxes. Direct taxes consists mainly income taxes while indirect taxes are mainly composed of value added tax (VAT), excise taxes, and custom duties (ECC, 2005).

Income tax of Ethiopia is based on the new Income Tax Proclamation No. 979/2016. Income is defined as every sort of economic benefit including non-recurring gains in cash or in kind, from whatever source directed and in whatever form paid credited or received. The proclamation governing income uses scheduler system of taxation. As per this proclamation, income is classified for income tax purposes according to its nature and source. The classifications into which the income falls are known as Schedules. The income tax proclamation classified income in accordance with its nature in to five schedules as follows: (A) income from employment, (B) income from rental of buildings, (C) income from business, (D) other income, and (E) exempt income.

This study focused on schedule ' $\mathrm{D}$ ' income tax in the case of selected branch office. Schedule ' $\mathrm{D}$ ' income refers to other incomes which are not scheduled under A, B, C, and E including income from royalties; income from rendering of technical service, income from game of chance; dividend income, from casual rental of property; interest income on deposit and gain on transfer of certain investment property. On the basis of the above background, the study tried to examine the practices of ERCA West Addis Ababa Medium Taxpayers' Branch on taxes levied and collected from income scheduled under ' $D$ ' i.e. other income. 


\subsection{Statement of the Problem}

A government finances its expenditures through the fund acquired from the service given by the government, tax, loan and donation. From all sources of finance, tax is the major source; however, in most developing countries including Ethiopia, it is a common phenomenon to notice serious problems in developing adequate tax systems that permits a government to sufficiently finance its expenditures (Gebremariam, 2010). Ethiopia has been experienced a consistent surplus of expenditure over revenue for sufficiently long period of time (Ayele, Getnet, \& Bekalu, 2017). Regardless of the country introduced a number of rules, systems and methods aiming tax collection as a major source of public revenue, the required result is not achieved yet (ERCA, 2015).

Precisely, this low revenue yield of taxation can be attributed to the fact that tax provisions are not properly enforced either on account of the inability of administration to cope with them or on account of straight forward collusion between the tax administration and taxpayers (Tanzi \& Howell, 2001; Gebremariam, 2010). In this regard identifying the problems on tax assessment and collection of each schedule at each branch office and taking corrective measures need attention since they have adverse effects on the overall revenue of the government.

However, most of previous studies in Ethiopia focused on general problems of taxation, rental income tax and business income tax. Besides without evidence it is difficult to convince the concerning body need for changes in practices. Therefore, the main motive to undertake this research was to fill the research gap that were not addressed by any one of the earlier studies, specifically trends and issues associated with other income called schedule ' $\mathrm{D}$ ' income tax administration at ERCA West Addis Ababa Medium Taxpayers Branch. This study provides novel contribution to existing body of knowledge where limited studies exist in the case of tax schedule ' $\mathrm{D}$ ' income tax in Ethiopia.

\subsection{Objective of the Study}

The overall objective of this research was to examine trends and issues related to other income tax administration in the case of ERCA West Addis Ababa Medium Taxpayers Branch. Specific objectives were:

- To describe the current trends of other income tax collection at the case branch

- To assess the compliance level of other income tax at the case branch

- To identify the tax evasion problem in respect of other income tax at the case branch

\section{Research Design and Methodology \\ 2.1. Research Design}

According to Sekaran (2003) a research design is set up to decide on, among other issues, how to collect further data, analyze and interpret them, and to provide an answer to the problem. It is a framework or blueprint for conducting a research. It details the procedures necessary for obtaining the information needed to structure the research problem (Kothari, 2004). In this research study, the main objective is to examine the trends and issues related to other income tax administration in the case of ERCA West Addis Ababa Medium Taxpayers Branch. Thus, descriptive research design is viewed as an appropriate research design for this study to describe the other income tax administration practice of ERCA West Addis Ababa Medium Taxpayers Branch. Descriptive research studies are those studies which are concerned with describing the characteristics of a particular individual, or of a group. It also involves events that have already taken place and may be related to present conditions (Kothari, 2004).

\subsection{Sample Selection}

Officials at ERCA West Addis Ababa Medium Taxpayers' Branch were the target population of the study. As it is impossible to collect from the whole population because the numbers were not manageable, the required data was collected from the sample respondent of the branch office staff. Survey sampling is the process of choosing from a much large population, a group about which the researcher wishes to make statements so that the selected part represents the total group (Creswell W. J., 2003). This involves elements of the study sample frame, sample size, and sampling techniques.

Sampling frame is a complete list of the study population. For this study, the sampling frame was officers at ERCA West Addis Ababa Medium Taxpayers' Branch which are directly responsible for the assessment and collection of taxes. The total number of officers directly responsible for tax assessment and collection officers were 109 until the conduct of the survey/August, 2018.

Determination of economical sample size is a major challenge for a researcher in conducting a survey. There is no a standard rule for the determination of sample size. Both large and small sample sizes have their own limitations. Too large a sample might become unwieldy and too small a sample might be unrepresentative. What matters in the determination of sample size is representativeness of the sample to a population. Therefore, the correct sample size depends on the purpose of the study and the nature of the population under scrutiny (Creswell J. W., 2009). By convenience, most researchers take 10 percent of a population to determine their sample size. Therefore, the researcher also believed that taking about 30 percent of the sample frame is representative. As stated 
by Tesfu (2012), for a homogenous population this much sample size is believed to be representative (See for example Cohen et al., 2005).

The sampling technique used for this research was probability type of sampling. Probability sampling involves selecting elements randomly in that the selection of any one element is independent of the selection of the other elements. Given that the researcher believed that all units of the sample frame provide similar information for the study probability sampling was employed. There are different methods of probability sampling. Among this, simple random sampling is the most basic selection method in which each element of the population has equal or nonzero chance of being selected. It the best way of ensuring that sample is unbiased (Cooper \& Schindler, 2008). Hence, simple random probability sampling is appropriate, and the researcher used lottery method to select the survey respondents.

\subsection{Source of Data and Collection Instruments}

The research basically used primary sources for firsthand information to achieve the objectives of the research. The primary data was obtained through distributing self-administrated questionnaires (both open and closed-ended questions) for informants. Mixed questionnaires have many merits; the most important of this advantage is its considerable flexibility (Creswell W. J., 2003). Semi structured interview with concerned bodies was conducted. It allowed the investigator some degree of flexibility at the time of interviewing for the pursuit of unexpected line of inquiry which was raised at the study progresses. Questions in the interview check list were constructed based on the review of literature.

Secondary data were collected through the inspection of all available official documents (published and unpublished) and records relating to the case under study; proclamations about taxes, policies and procedures of the taxes and other taxing systems magazines, brochures that have been approved and issued by ERCA. In addition, previous research papers, books, websites and other related documents were reviewed and used.

\subsection{Method of Data Analysis}

After gathering the data, its accuracy and analytical validity was checked. Next to data arranged so as to make it easy for further processing. The analysis part was concerned with the conversion of raw data in to information was used for conclusion and recommendation. Here tabulation and percentages were used to make the analysis purpose easier. After the data analyzed it was converted into understandable form. There were also reasonable explanation for the raw data obtained; finally the task of presentation were accomplished on the arranged time.

\section{Results and Discussion}

\subsection{Schedule 'D' Income Tax Administration}

In order to raise adequate revenue to minimize revenue shortfall, ERCA has 30 branch offices all over the country. ERCA West Addis Ababa Medium Taxpayers' Branch is one of the branches ERCA has. The branch office currently has more than 250 employees at the office located near Beklo Bet, on Debrezeit Road. According to ERCA (2016), medium taxpayers are those companies with a yearly sales turnover between one million ETB and 27 million ETB while, those with less than a million ETB in annual sales are classified as small taxpayers. Companies who have an annual sales turnover 27 million ETB and greater categorized as large taxpayers. First grade contractors only private limited and share companies, companies engaged in the mining, petroleum exploration, banking and insurance sectors are included in the large taxpayers' category regardless of their annual sales turnover.

ERCA West Addis Ababa Medium Taxpayers' Branch is the office, which is delegated to assess and collect both direct and indirect taxes from medium taxpayers residing in Gulele, Kirkos, KolfeKeranio, Lideta and Addis Ketema districts. In the branch office, income tax assessments and collections are carried out according to Income Tax Proclamation No. 979/2016. The proclamation governing income uses scheduler system of taxation. As per this proclamation, income classified income in accordance with its nature in to five schedules; (A) Income from employment, (B) Income from rental of buildings, (C) Income from business, (D) Other income, and (E) Exempt income. This study focused on schedule ' $\mathrm{D}$ ' income which refers to other incomes which are not scheduled under A, B, C, and E. Schedule ' $\mathrm{D}$ ' income includes but not limited to income from royalties, income from rendering of technical service, income from game of chance, dividend income, undistributed profit, repatriated profit, from casual rental of property; interest income on deposit and gain on transfer of certain investment property.

Among the incomes under schedule ' $\mathrm{D}$ ' the main expected taxes by West Addis Ababa Medium Taxpayers' Branch are taxes on; income from game of chance, dividend income, gain on transfer of shares, income from royalties, and interest income on deposit. The objective of the empirical data was to examine the above existing taxes on incomes under schedule ' $\mathrm{D}$ ' tax administration by West Addis Ababa Medium Taxpayers' Branch.

Most of schedule ' $\mathrm{D}$ ' income taxes are administrated through agents who make payments of schedule ' $\mathrm{D}$ ' incomes to recipients. The agent company paying a royalty and a dividend to recipient shall withhold tax from the gross amount of the royalty and dividend at the rate of $10 \%$. A financial institution paying interest on a savings 
deposit shall withhold tax from the gross amount of the interest at the rate of $5 \%$ whereas, in any other cases a company paying an interest withhold tax from the gross amount of an interest at the rate of $10 \%$. In the case of winnings from a game of chance above ETB1,000 the paying party shall withhold tax from the gross amount of the winnings at the rate of $15 \%$.At the time of withholding tax from the above schedule ' $D$ ' incomes, a withholding agent shall provide the recipient of the schedule ' $\mathrm{D}$ ' income with a withholding tax certificate in the approved form.

Tax that a withholding agent is required to withhold from schedule ' $\mathrm{D}$ ' income shall be paid to the Authority within 30 days after the end of the month in which the schedule ' $\mathrm{D}$ ' income was paid. A withholding agent required to pay withholding tax shall file a withholding tax declaration in the approved form with the payment. If a withholding agent fails to withhold schedule ' $\mathrm{D}$ ' income tax, the withholding agent shall be personally liable to pay the amount of tax to the Authority to recover the tax paid from the recipient of the payment.

\subsection{The Trend of other Income Tax Revenue}

Table 3.1: Tax from dividend, game and lottery

\begin{tabular}{cccccc}
\hline \multirow{2}{*}{$\begin{array}{c}\text { Budget } \\
\text { Year }\end{array}$} & Planned & Current Year & Last Year & \%ge Change & \multirow{2}{*}{ Achievement in Percent } \\
\cline { 2 - 5 } & & 127.93 & 66.92 & $91.17 \%$ & $8.46 \%$ \\
\hline 2008 & 1511.64 & 164.06 & 127.93 & $28.24 \%$ & $85.29 \%$ \\
\hline 2009 & 192.36 & 91.97 & 164.06 & $-43.94 \%$ & $73.49 \%$ \\
\hline 2010 & 125.15 & & & \\
\hline
\end{tabular}

Source: ERCA West Addis Ababa Medium Taxpayers’ Branch Report, 2018.

The table 3.1 above depicts tax revenue from dividend income and winnings of game for three consecutive years. As can be observed from the table the amount of tax collected was increased by 91.17 percent in the budget year 2008 relative to 2007 but the amount collected was far from planned. In the year 2009 the office collected 85.29 percent of the planned amount and the collected amount was increased by 28.24 percent compared with preceding year. Despite the office achieved 73.49 percent of its plan in the year 2010 the amount of tax collected from dividend, game and lottery decreased by 43.94 percent relative to previous year.

Generally, the amount of income tax on dividend and winnings of game was increased in the year 2008 and 2009 but in the budget year 2010 the amount highly decreased. In addition, the growth rate of tax revenue on dividend and winnings of game was not consistent with the plan of branch office. From this we say that the office plan regarding the tax revenue from dividend income and winnings of game and the collected amount in the recent three consecutive years was declining. This implies that the office was trying to achieve its plan by decreasing the planned amount rather than working on the factors that resulted in less amount of tax collection from dividend income and winnings of game.

The below table 3.2 shows the trend of tax revenue collected from capital gain on share of stock for recent three years. As can be observed from the table in the year 2008 the branch office collected only 5.12 percent income tax from gain on share of its plan which was lesser by 59.15 percent than prior year. However, in 2009 the office collected 72.13 percent greater amount than 2008 collection where the office achieved 113.86 percent of its planned amount. Also in the year 2010 the office approached to collect its planned amount but tax revenue collected from capital gain on share collected was decreased by 16.93 percent compared with 2009 .

Table 3.2: Tax from gain on share

\begin{tabular}{cccccc}
\hline $\begin{array}{c}\text { Budget } \\
\text { Year }\end{array}$ & Planned & Current Year & Last Year & \%oge Change & Achievement in \\
\cline { 3 - 5 } Percent
\end{tabular}

Source: ERCA West Addis Ababa Medium Taxpayers’ Branch Report, 2018.

The above table generally indicates that tax revenue collected from capital gain on share of stock for recent three years was fluctuating, but the office plan was declined throughout these years. This indicates that the branch office weak to plan based on research or weak on making researches and or weak in enforcing to achieve its plan.

The table below shows the recent three years trends of revenue collected from tax on royalties by ERCA West Addis Ababa Branch office. In the budget year 2008 the branch office collected 101.79 percent greater amount than prior year but far from its plan. The office collected 86.07 percent of its planned amount in 2009 and the collected amount by the office also increased by 16.15 percent in 2009 relative to 2008 . Further, the branch office increased the amount of royalties' tax collection by 115.24 percent and achieved 279.01 percent of its plan. 
Table 3.3: Tax from Royalties

\begin{tabular}{cccccc}
\hline \multirow{2}{*}{$\begin{array}{c}\text { Budget } \\
\text { Year }\end{array}$} & Planned & Current Year & Last Year & \%oge Change & $\begin{array}{c}\text { Achievement in } \\
\text { Percent }\end{array}$ \\
\hline 2008 & 85.18 & 4.52 & 2.24 & $101.79 \%$ & $5.31 \%$ \\
\hline 2009 & 6.1 & 5.25 & 4.52 & $16.15 \%$ & $86.07 \%$ \\
\hline 2010 & 4.05 & 11.3 & 5.25 & $115.24 \%$ & $279.01 \%$ \\
\hline
\end{tabular}

Source: ERCA West Addis Ababa Medium Taxpayers' Branch Report, 2018.

The recent three years trends of revenue collected from tax on royalties by the branch office was increasing as indicated in the above table, but the planned amount by the office was decreasing. This shows that the office was capable of planning the amount of tax revenue from royalties but improved its collection.

Table 3.4: Tax from interest on deposit

\begin{tabular}{cccccc}
\hline \multirow{2}{*}{$\begin{array}{c}\text { Budget } \\
\text { Year }\end{array}$} & Planned & \multicolumn{3}{c}{ Actually Collected } & \multirow{2}{*}{ Achievement in Percent } \\
\cline { 3 - 5 } & & Current Year & Last Year & \%oge Change & \\
\hline 2008 & 0.24 & 0.02 & 0.04 & $-50.00 \%$ & $8.33 \%$ \\
\hline 2009 & 0.07 & 0.02 & 0.02 & $0.00 \%$ & $28.57 \%$ \\
\hline 2010 & 0.38 & 0.04 & 0.02 & $100.00 \%$ & $10.53 \%$ \\
\hline
\end{tabular}

Source: ERCA West Addis Ababa Medium Taxpayers' Branch Report, 2018.

The tax collected from interest on deposit in 2008 was decreased by 50 percent relative to prior year and the office achieved only 8.33 percent of its plan as shown by the above table 3.4 in the budget year 2009 the branch office collected the same amount of tax revenue from interest on deposit which was 28.57 percent of the planned amount. The tax revenue collected from interest on deposit in 2010 was twice of the 2009 but only 10.53 percent of the amount planned by the office in the budget year. Tax revenues collected from interest on deposit was fluctuating during the recent three years and the branch office achieved below its plan during those years. This may indicate that the branch office was not planning well or not strong enough to collect the planned amount.

\subsection{Survey Result}

3.3.1. Questionnaires Response Rate

Table 3.5: Questionnaire Response Rate

\begin{tabular}{c|cc}
\hline Particulars & Frequency & Percentage \\
\hline Responded & 24 & $72.7 \%$ \\
Non respond & 9 & $27.3 \%$ \\
Total & $\mathbf{3 3}$ & $\mathbf{1 0 0 \%}$ \\
\hline
\end{tabular}

Source: Survey result, 2018.

The objective of this study was to investigate other income tax administration of Ethiopia in the case of ERCA West Addis Ababa Medium Taxpayers' Branch. In order to achieve this objective, 33 self-administered semi structured questionnaires were distributed to the sample staff of the branch office to which the researcher received a $72.7 \%$ response rate, whereas the remaining did not returned the questionnaires (Table 3.5). The response rate would not affect the representativeness because it accounts about 22 percent of the sample frame. 


\subsubsection{Demographic Characteristics of the Respondents}

Table 3.6: Demographic characteristics

\begin{tabular}{|c|c|c|c|}
\hline Characteristics & Frequency & Percentage & Total \\
\hline \multicolumn{4}{|l|}{ A) $\mathrm{Sex}$} \\
\hline Male & 15 & $62.5 \%$ & \multirow[t]{2}{*}{24} \\
\hline Female & 9 & $37.5 \%$ & \\
\hline \multicolumn{4}{|l|}{ B) Academic level } \\
\hline Bachelor's degree & 21 & $87.5 \%$ & \multirow[t]{2}{*}{24} \\
\hline Master's degree & 3 & $12.5 \%$ & \\
\hline \multicolumn{4}{|l|}{ C) Working Experience } \\
\hline Less than 5 years & 5 & $20.8 \%$ & \multirow{4}{*}{24} \\
\hline 6 to 10 years & 7 & $29.2 \%$ & \\
\hline 11 to 15 years & 8 & $33.3 \%$ & \\
\hline Over 15 years & 4 & $16.7 \%$ & \\
\hline \multicolumn{4}{|l|}{ D) Position /responsibility } \\
\hline Team leader & 1 & $4.2 \%$ & \multirow{4}{*}{24} \\
\hline Tax collectors & 11 & $45.8 \%$ & \\
\hline Tax assessment officer & 7 & $29.2 \%$ & \\
\hline Audit officer & 5 & $20.8 \%$ & \\
\hline
\end{tabular}

Source: Survey result, 2018.

The demographic characteristics of the respondents included; sex, level of education, work experience and position. Table 3.6, depicts background of sample respondents from ERCA West Addis Ababa Medium Taxpayers' Branch. According to the table above the majority of the participants in this study were male expressed by an overall $62.5 \%$ whilst that of the females was $37.5 \%$. The imbalance of gender does not have an impact on the factors to be examined in this research. As it can be seen from table 3.6 the respondent has position ranging from team leader to tax collector. Regarding their educational background, $21(87.5 \%)$ of the respondent are first degree holder and $3(12.5 \%)$ have master degree. According to the table 3.6,20.8\% of the respondents have 0-5 Years' experience, $29.2 \%$ have 6-10 years, $33.3 \%$ have $11-15$ years, and $1.7 \%$ of them have more than 15 years' experience. This indicates the research respondent has sufficient educational background and working experience which makes the information obtained from these respondents to have a better quality.

\subsubsection{Survey Response Regarding to Other Income Tax Administration at Branch Office}

A likert six scale questioner which ranges "Strongly Disagree", "Disagree", "Inclined to Disagree", "Inclined to agree", "Agree", and "strongly agree" was used by the researcher to analyze the attitude of the participants towards the efforts made by the branch office to efficient other income tax administration.

As depicted by the table 3.7 about 78 percent of the branch office survey respondents either inclined to agree or agreed or strongly agree with the statement that due to the office put less effort to determine source of schedule ' $\mathrm{D}$ ' income, other income tax collection could result in inefficiency. This indicates that the majority of officials included in the sample believe that schedule ' $\mathrm{D}$ ' income tax collection could result in inefficiency due to the office put less effort to determine source of schedule ' $\mathrm{D}$ ' income. This indicates that the efforts made by the office significantly determine the efficiency of schedule ' $\mathrm{D}$ ' income tax collection.

Table 3.7: Efforts and Other Income Tax Collection Efficiency

\begin{tabular}{|c|c|c|c|c|c|c|c|}
\hline No. & Statements & 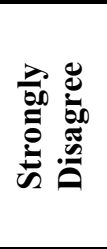 & 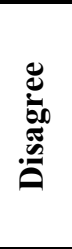 & 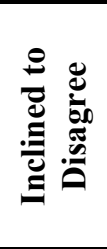 & 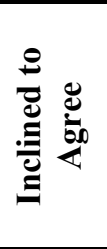 & 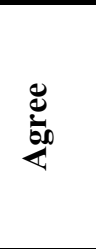 & 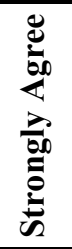 \\
\hline 1. & $\begin{array}{l}\text { Due to the office put less effort to determine all sources } \\
\text { of schedule ' } \mathrm{D} \text { ' income, other income tax collection } \\
\text { could result in inefficiency. }\end{array}$ & 0 & 4.4 & 17.4 & 39.1 & 30.4 & 8.7 \\
\hline \multicolumn{8}{|c|}{$\begin{array}{l}\text { Source: Survey result, } 2018 \text {. } \\
\text { In relation to this the survey respondents rated the efforts made by ERCA West Addis Ababa Mediun } \\
\text { Taxpayers Branch with different parameters. The survey result in the table } 3.8 \text { below indicated that half of th } \\
\text { survey respondents rated the branch office either poor or very poor in creating awareness regarding schedule ' } D \\
\text { income tax. While the remaining respondents claim that the branch office's effort to create awareness is good o } \\
\text { very good. }\end{array}$} \\
\hline
\end{tabular}


Table 3.8: Efforts Made by ERCA West Addis Ababa Medium Taxpayers Branch

\begin{tabular}{llcccc}
\hline No. & \multicolumn{1}{c}{ Parameters } & $\begin{array}{l}\text { Very } \\
\text { Poor }\end{array}$ & Poor & Good & $\begin{array}{c}\text { Very } \\
\text { Good }\end{array}$ \\
\hline 1. & Awareness creation & $16.67 \%$ & $33.33 \%$ & $37.50 \%$ & $12.50 \%$ \\
2. & Information Technology (IT) facilities & $29.17 \%$ & $41.67 \%$ & $25.00 \%$ & $4.17 \%$ \\
3. & Law enforcement & $25.00 \%$ & $33.33 \%$ & $25.00 \%$ & $16.67 \%$ \\
4. & Penalties or imposition of sanctions by tax authority for & & & & \\
& tax failures & $25.00 \%$ & $37.50 \%$ & $20.83 \%$ & $16.67 \%$ \\
5. & Organized data handling system & $29.17 \%$ & $37.50 \%$ & $25.00 \%$ & $8.33 \%$ \\
\hline
\end{tabular}

Source: Survey result, 2018.

About 71 percent of the survey respondents rated the branch office either poor or very poor with regard to information technology facilities while around 29 percent of the respondents rated good or very good. This shows that the branch office is not put enough information technology facilities which are believed to improve schedule ' $\mathrm{D}$ ' income tax assessment and collection activities.

With regarding to the law enforcement about 58 percent of the respondents rate the branch office either poor or very poor, while around 42 percent response shows good or very good. This further shows the weakness of branch office in enforcing law as majority of the staff participated in the survey indicated.

According to survey result the branch office is regarded as not strong in imposing penalties for delaying and not paying by the taxpayers. This shown by 62.5 percent of survey respondents gave the branch office either poor or very poor in imposing penalties by delaying and not paying taxpayers, while the remaining 37.5 percent of the response was either good or very good.

When the respondents asked to evaluate the branch office in relation to organized data handling system, about 67 percent of the respondents rated either poor or very poor.

The table 3.9 depicts the survey results with regard to ERCA West Addis Ababa Medium Taxpayers' Branch staff perception towards schedule ' $D$ ' income tax administration at their office.

62.5 percent of the respondents believe that the office run Schedule ' $D$ ' income tax collection and administration having most sophisticated technology systems. This indicated by the responses 29.2 percent, 25 percent, and 8.3 percent inclined to agree, agree, and strongly agree respectively.

Despite the sophisticated technology systems the majority of the respondents state that the procedures followed by the office to collect schedule ' $\mathrm{D}$ ' income tax is clear, simple and user friendly as shown by responses of 33.3 percent, 29.2 percent, and 8.3 percent inclined to agree, agree, and strongly agree respectively.

An enquiry into to the staff of their perception towards coordination of schedule ' $\mathrm{D}$ ' income tax with other types of taxes revealed 62.5 percent of the respondents judge that schedule ' $\mathrm{D}$ ' income tax is closely coordinated and performed with other tax types, income tax in particular, in their office. This shown by the responses of about 33.3 percent, 20.8 percent, and 8.3 percent inclined to agree, agree, and strongly agree respectively.

\section{Table 3.9: Schedule 'D' Income Tax Administration System}

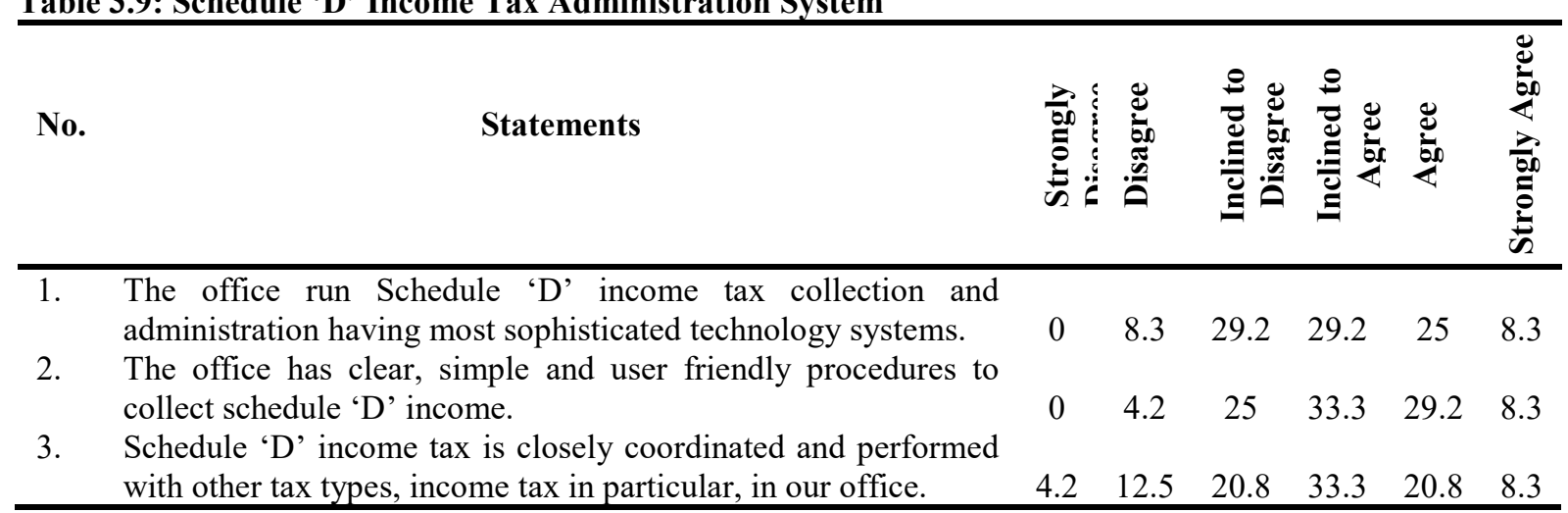

Source: Survey result, 2018. 


\begin{tabular}{|c|c|c|c|c|c|c|c|}
\hline No. & Statements & 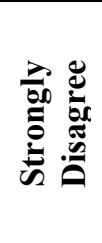 & 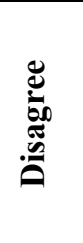 & 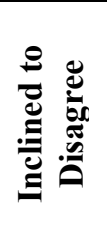 & 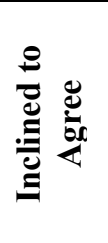 & $\underset{\square}{\stackrel{\Xi}{0}}$ & 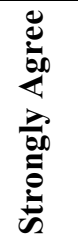 \\
\hline 1. & $\begin{array}{l}\text { Staffs have well enough knowledge in dealing with schedule } \\
\text { 'D' income tax collection procedures }\end{array}$ & 0.00 & 16.7 & 16.7 & 20.8 & 33.3 & 12.5 \\
\hline 2. & $\begin{array}{l}\text { Strong knowledge capacity of officials' benefited the } \\
\text { effective schedule 'D' income tax collection and } \\
\text { administration }\end{array}$ & 12.5 & 29.2 & 12.5 & 16.7 & 29.2 & 0.00 \\
\hline 3. & $\begin{array}{l}\text { Using the knowledge they have Authority created positive } \\
\text { attitude with taxpayers }\end{array}$ & 0.00 & 29.2 & 20.8 & 16.7 & 33.3 & 0.00 \\
\hline 4. & $\begin{array}{l}\text { The office provides cross functional training for employees so } \\
\text { we have an understanding of the entire system of tax } \\
\text { administration }\end{array}$ & 0.00 & 25.0 & 16.7 & 25.0 & 33.3 & 0.00 \\
\hline
\end{tabular}
Source: Survey result, 2018.

According to the table 3.10 , about 67 percent the respondents either strongly agreed or agreed or inclined to agree with the statement that staffs at the branch office have well enough knowledge in dealing with schedule ' $D$ ' income tax collection procedure. While, about 33 percent of the respondents inclined disagree or disagree to the above statement.

However, about 54 percent of the respondents' either strongly disagreed or disagreed or inclined to disagree with the statement that strong knowledge capacity of officials' benefited the effective schedule ' $\mathrm{D}$ ' income tax collection and administration. Whereas, about 46 percent of the respondents inclined agree or agree to the above statement.

50 percent of the respondents either agreed or inclined to agree with the statement that using the knowledge they have, the branch office created positive attitude with taxpayers. Where, the remaining 50 percent of the respondents inclined disagree or disagree to the above statement.

About 58 percent of the respondents either agreed or inclined to agree with the statement that the office provides cross functional training for employees so we have an understanding of the entire system of tax administration. Though, about 42 percent of the respondents inclined disagree or disagree to the above statement. Table 3.11: Schedule ' $D$ ' Income Tax Compliance, Evasion and Conflict Resolution

\begin{tabular}{|c|c|c|c|c|c|c|c|}
\hline No. & Statements & 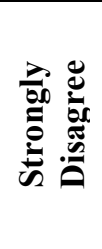 & 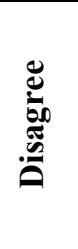 & 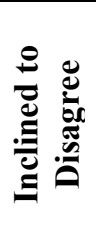 & 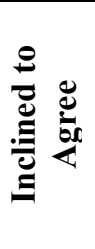 & 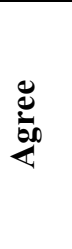 & 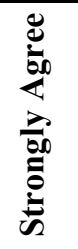 \\
\hline 1. & Less penalty stated by law encourages evasion. & 8.33 & 29.2 & 20.8 & 16.7 & 25.0 & 0.00 \\
\hline 2. & Low awareness level of taxpayers led to evasion. & 12.5 & 37.5 & 16.7 & 12.5 & 20.8 & 0.00 \\
\hline 3. & $\begin{array}{l}\text { Low tax morale on the part of the citizenry resulted in non- } \\
\text { compliance. }\end{array}$ & 0.00 & 12.5 & 4.2 & 20.8 & 45.8 & 16.7 \\
\hline 4. & $\begin{array}{l}\text { The branch offices strictly penalize tax payers who engaged in } \\
\text { tax evasion. }\end{array}$ & 8.33 & 37.5 & 16.7 & 16.7 & 20.8 & 0.00 \\
\hline 5 . & $\begin{array}{l}\text { Taxpayers usually complain about the way schedule ' } D \text { ' } \\
\text { income tax is assessed and collected. }\end{array}$ & 4.17 & 29.2 & 20.8 & 25.0 & 20.8 & 0.00 \\
\hline 6. & $\begin{array}{l}\text { There is a neutral free administrative tax appeal committee to } \\
\text { hear schedule ' } \mathrm{D} \text { ' income taxpayers' complaint. }\end{array}$ & 0.00 & 25.0 & 16.7 & 20.8 & 37.5 & 0.00 \\
\hline
\end{tabular}

Source: Survey result, 2018

According to the above table 3.11, about 58 percent of the respondents' inclined to disagree or disagreed or strongly disagreed with the statement that less penalty stated by law encourages tax evasion, whereas about 42 percent of the survey respondents responded inclined to agree or agree to the above statement.

About 67 percent of tax officials' survey respondents indicated that they inclined to disagree or disagreed or strongly disagreed with the statement that low awareness level of taxpayers led to tax evasion. The remaining around 33 percent of the respondents inclined to agree or agreed to the above statement.

About 83 percent of tax officials' survey respondents indicated that they inclined to agree or agreed or strongly agreed with the statement that low tax morale on the part of the citizenry resulted in non-compliance. 
Whereas, only about 17 percent of the respondents inclined to disagree or disagreed to the above statement.

According to the above table 3.11, 62.5 percent of the respondents' inclined to disagree or disagree, or strongly disagree with the statement that the branch offices strictly penalize tax payers who engaged in tax evasion, while the remaining 37.5 percent of the survey respondents responded inclined to agree or agree to the above statement.

About 54 percent of tax officials survey respondents indicated that they inclined to disagree or disagreed or strongly disagreed with the statement that taxpayers usually complain about the way schedule ' $D$ ' income tax is assessed and collected., while about 46 percent of the respondents inclined to agree or agreed to the above statement.

About 58 percent of tax officials' survey respondents indicated that they inclined to agree or agreed with the statement that there is a neutral free administrative tax appeal committee to hear schedule ' $\mathrm{D}$ ' income taxpayers' complaint. The remaining 42 percent of the respondents inclined to disagree or disagreed to the above statement. Table 3.12: Possible Measures to Improve Schedule ' $D$ ' Income Tax

\begin{tabular}{|c|c|c|c|c|c|c|c|}
\hline No. & Statements & 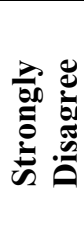 & 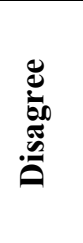 & 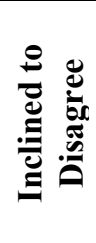 & 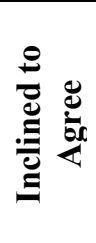 & 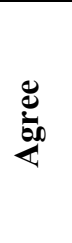 & 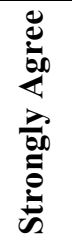 \\
\hline 1. & Strengthening legal enforcement and penalties. & $\begin{array}{c}16 . \\
7\end{array}$ & 37.5 & 20.8 & 12.5 & 12.5 & 0 \\
\hline 2. & $\begin{array}{l}\text { Creating closer relationship with taxpayers and the public in } \\
\text { schedule ' } D \text { ' income tax assessment and collection regards. }\end{array}$ & 0 & 4.2 & 16.7 & 25 & 33.3 & 20.8 \\
\hline 3. & Educating the taxpayers and conducting consultation sessions. & 0 & $\begin{array}{c}16 . \\
7\end{array}$ & 8.3 & 20.8 & 29.2 & 25 \\
\hline 4. & $\begin{array}{l}\text { Making schedule ' } D \text { ' income tax assessment and collection } \\
\text { procedures simple and transparent. }\end{array}$ & 4.2 & 20.8 & 12.5 & 20.8 & 25 & 16.7 \\
\hline 5. & $\begin{array}{l}\text { Utilizing advanced technology to determine of the source of } \\
\text { income. }\end{array}$ & 0 & 4.2 & 12.5 & 29.2 & 29.2 & 25 \\
\hline
\end{tabular}
Source: Survey result, 2018.

When respondents are asked about measures should be taken to improve schedule ' $\mathrm{D}$ ' income tax collection and compliance level, 75 percent of the respondents either inclined to disagree or disagreed or strongly disagree with statement suggesting strengthening legal enforcement and penalties.

About 79 percent of tax officials survey respondents indicated that they inclined to agree or agreed or strongly agreed with the statement that creating closer relationship with taxpayers and the public in schedule ' $\mathrm{D}$ ' income tax assessment and collection regards.

Also, 75 percent of the respondents' inclined to agree or agree, or strongly agree with the statement that educating the taxpayers and conducting consultation sessions would improve schedule ' $\mathrm{D}$ ' income tax collection and compliance.

About 63 percent of tax officials' survey respondents inclined to agree or agreed or strongly agreed with the statement that making schedule ' $\mathrm{D}$ ' income tax assessment and collection procedures simple and transparent would improve schedule ' $\mathrm{D}$ ' income tax compliance level.

According to the above table 4., about 83 percent of the respondents' inclined to agree or agree, or strongly agree with the statement that utilizing advanced technology to determine of the source of income would improve schedule ' $\mathrm{D}$ ' income tax collection and compliance level.

\subsection{Discussions on Major Results}

The secondary data collected from ERCA West Addis Ababa Medium Taxpayers Branch indicates that among tax from schedule ' $\mathrm{D}$ ' income the office plans collects income tax on dividend and winnings of game, capital gain on share of stock, royalties, and interest on deposit. Commonly the tax collected by the office from schedule ' $\mathrm{D}$ ' income has no consistent trend in the recent three years and the office plan also went up and down. In addition, most of the schedule ' $\mathrm{D}$ ' income tax revenue collected by the branch office went down and declining throughout the recent three years. This indicates that there was problem in the tax assessment and collection practice in relation with schedule ' $D$ ' income tax by the branch office. This low revenue yield of taxation can be attributed to the fact that tax provisions are not properly enforced either on account of the inability of administration to cope with them or on account of straight forward collusion between the tax administration and taxpayers.

As discussed in the above the main weakness of ERCA West Addis Ababa Medium Taxpayers Branch was either not planning well or not strong enough to collect the planned amount. With regarding to planning the office changing or manipulating the amount to be collected from schedule ' $\mathrm{D}$ ' income only based on prior year collection 
because the office plan was consistently vary with previous year's collection. This shows that the office doesn't made detail researches before planning to decide on the amount to be collected from schedule ' $\mathrm{D}$ ' income tax, reflecting little effort made the branch office to increase the collection of schedule ' $\mathrm{D}$ ' income tax.

In relation to the level of efforts made by the office and schedule ' $\mathrm{D}$ ' income tax collection efficiency, majority of tax officials participated in this study survey also confirms that inefficiency of schedule ' $\mathrm{D}$ ' income tax collection would result from less effort by the office to determine source of schedule ' $\mathrm{D}$ ' income tax. In this regard the survey result indicated that the branch office effort by using information technology, enforcing tax laws, imposing penalties, and developing organized data handling system was very weak. Moreover, the survey result shown that the awareness creation efforts by the branch office was not good enough which needs to be improved.

Despite less effort by the branch office and sophisticated technology systems the majority of the respondents state that the procedures followed by the office to collect schedule ' $\mathrm{D}$ ' income tax is clear, simple and user friendly. Based on the survey response this could be attributed to coordination of schedule ' $\mathrm{D}$ ' income tax with other types of taxes particularly with income taxes. Otherwise, may be due to the fact that most of schedule ' $\mathrm{D}$ ' income taxes collected through agents who withhold tax from schedule ' $\mathrm{D}$ ' income recipients. Although it is stated that there is a neutral free administrative tax appeal committee, the collection of schedule ' $\mathrm{D}$ ' income tax through agent company could account for the low level complain by taxpayers specifically concerning with schedule' D' income tax as indicated by survey result.

One of the major factor for efficiency of tax office is skilled manpower. As the survey result shown that the branch office provides cross functional training for employees so they have an understanding of the entire system of tax administration. In addition, staff at the branch office have well enough knowledge in dealing with schedule ' $\mathrm{D}$ ' income tax collection procedure. However, the branch office did not well benefited strong knowledge capacity of officials' neither to improve schedule ' $\mathrm{D}$ ' income tax collection and administration nor create positive attitude with taxpayers. This indicates that the branch office was not efficiently use its human resource by promoting team work and integrity.

Besides weak enforcement of the branch office by strictly imposing penalty on tax payers who engaged in tax evasion, the survey result revealed less penalty stated by law could also encourages tax evasion. The information gathered from branch office indicates that one major problem observed from the tax office was lack of stiff search and control of registered and unregistered schedule ' $\mathrm{D}$ ' income taxpayers.

The reason for inefficiency of schedule ' $\mathrm{D}$ ' income tax is not only the weakness of ERCA West Addis Ababa Medium Taxpayers Branch office, but the non-compliance and tax evasion by the taxpayers. According to the information obtained from the office there are taxpayers owning different business entities but with different TIN numbers. Furthermore, the prevalence of firms performing business without being registered or having TIN created duplication and falsification of address. In addition, one of the biggest challenges in relation to schedule ' $\mathrm{D}$ ' income tax faced by the authority was taxpayers' submitted unreliable signed document to the tax authority. They produce two documents signed by both the recipient of schedule ' $\mathrm{D}$ ' income and Agent Company who withhold schedule ' $\mathrm{D}$ ' income tax and submit the one with the reduced amount of agreement.

The survey result justifies that the low compliance level of schedule 'D' income taxpayers couldn't arises from the taxpayers' knowledge gap rather it could be raised from the low tax moral and attitude of the citizen in general and branch office's taxpayers particularly towards paying tax.

Finally, to improve schedule ' $D$ ' income tax collection and compliance level, officials at ERCA West Addis Ababa Medium Taxpayers' Branch included in the sample suggested to create closer relationship with taxpayers and the public and to utilize advanced technology to determine of the source of income schedule ' $\mathrm{D}$ ' income. The survey respondents also put forward that strengthening legal enforcement and penalties could not be the solution rather educating the taxpayers and conducting consultation sessions to change the people's attitude could improve the tax revenue generally and schedule ' $\mathrm{D}$ ' income tax in particular.

\section{Conclusions and Recommendations}

\subsection{Conclusions}

The main objective of this study was to examine other income (schedule ' $\mathrm{D}$ ' income) tax administration issues in Ethiopia in respect of ERCA West Addis Ababa Medium Taxpayers Branch. In order to achieve this objective primary data and secondary data were gathered from the branch office and systematically analyzed. Primary data mainly obtained through self-administrated questioners which were distributed to the branch officials, whereas secondary data mainly obtained from the branch office reports and unpublished documents. The collected data were presented using percentage and tabulation. The study also analyzed the trend of schedule ' $D$ ' income tax collection in recent three years at ERCA West Addis Ababa Medium Taxpayers Branch.

The major results of the study indicates that ERCA West Addis Ababa Medium Taxpayers Branch was only plans and collects income tax on dividend and winnings of game, capital gain on share of stock, royalties, and interest on deposit among taxes from schedule ' $\mathrm{D}$ ' income. In addition, most of the schedule ' $\mathrm{D}$ ' income tax revenue collected by the branch office went down and declining throughout the recent three years. The main reason 
for inefficiency of schedule ' $\mathrm{D}$ ' income tax was less efforts made by the branch office in providing information technology, law enforcement, imposing penalties, developing organized data handling system, and awareness creation.

The reason for inefficiency of schedule ' $\mathrm{D}$ ' income tax is not only the weakness of ERCA West Addis Ababa Medium Taxpayers Branch office, but the non-compliance and tax evasion by the taxpayers. Despite the advantages of collecting schedule ' $\mathrm{D}$ ' income tax through Agent Company by making tax payment clear and simple. The major problem of collecting schedule ' $\mathrm{D}$ ' income tax is submitting unreliable signed document by producing two documents signed by both the recipient of schedule ' $D$ ' income and Agent Company who withhold schedule ' $\mathrm{D}$ ' income tax and submit the one with the reduced amount of agreement. The low compliance level of schedule ' $D$ ' income taxpayers couldn't arises from the taxpayers' knowledge gap rather it could be raised from the low tax moral and attitude of the citizen in general and branch office's taxpayers particularly towards paying tax.

\subsection{Recommendations}

Identifying the problems on tax assessment and collection of each schedule at each branch office and taking corrective measures need attention since they have adverse effects on the overall revenue of the government. Therefore, this study tried to analyze the trend of schedule ' $\mathrm{D}$ ' income tax collection and to identify problems associated with schedule ' $D$ ' income tax assessment at ERCA West Addis Ababa Medium Taxpayers Branch. This study suggests the branch office to take corrective actions to improve schedule ' $\mathrm{D}$ ' income tax collection and compliance level. Particularly the study suggests the branch office to create closer relationship with taxpayers and the public and to utilize advanced technology to determine of the source of income schedule ' $\mathrm{D}$ ' income tax. In addition, the study put forward that strengthening legal enforcement and penalties could not be the solution rather educating the taxpayers and conducting consultation sessions to change the people's attitude could improve the tax revenue generally and schedule ' $\mathrm{D}$ ' income tax in particular.

\section{References}

Asian Development Bank. (2001). Challenges of Tax Administration and Compliance. Tax Conference. Asian Development Bank.

Ayele, B. F., Getnet, B., \& Bekalu, T. (2017). Effectiveness on Tax Assessment and Collection Practice of Category "C" Tax Payers: The Case of Halaba City Administration. International Journal of Research in Management, Science and Technology, 7(13), 65-85.

Cohen, Manion, \& Marrison. (2005). Research Methods in Education (5th ed.). Taylor and Francis e-library.

Cooper, J., \& Schindler, M. (2008). Perfect Sample Size in Research. NewJersey: Macmillan.

Creswell, J. W. (2009). Editorial: Mapping the field of mixed methods research. Journals of Mixed Methods Research, 3(95), 95-109.

Creswell, W. J. (2003). Research Design: Qualitative, Quantitative and Mixed approaches (2nd ed.). New Delhi.

ECC. (2005). Taxation in Ethiopia: Direct and Indirect Taxes - Categories of Taxpayers Declaration of Income and Assessment of Taxes Tax Incent ives. Addis Ababa: Ethiopian Chambers of Commerce.

ERCA. (2015). Customer Charter. Addis Ababa: ERCA.

Gebremariam, A. G. (2010). Tax assessment and collection problems of Category "A" taxpayers: A case of Yeka Sub City. Masters Thesis. Addis Ababa, Ethiopia.

Graetz, M. J., \& Schenk, D. H. (2001). Federal Income Taxation: Principles and Policies (4th ed.). New York: Foundation Press.

Kangave. (2005). Improving Tax Administration: A Case Study of the Uganda Revenue Authority. Journal of African Law, 145-176.

Kothari, C. R. (2004). Research Methodology: Methods and Techniques (2nd Revised ed.). New Delhi: New Age International Publishers.

Negarit Gazeta. (2008). Ethiopian Revenue and Customs Authority Establishment Proclamation No 587/2008. Addis Ababa: FDRE.

Negarit Gazette. (2016). Income tax Proclamation No. 979/2016. Addis Ababa: FDRE.

Shina, E. S. (2014). Factors Affecting Fairness of Taxation on Category "B" Taxpayers. IFSMRC International Publications.

Tanzi, V., \& Howell, Z. (2001). Tax Policy for Developing Countries. Washington, D.C.: IMF.

Tesfu, F. F. (2012). The Adoption of International Financial Reporting Standards (IFRS) in Ethiopia: Benefits and Key Challenges. Addis Ababa: Addis Ababa University. 